\title{
Psychological Contracts, Work Behaviour and Turnover Intention in the Hong Kong Telecommunications Industry
}

\author{
Ruth W. Y. Ma, Eric C. K. Cheng* \\ Department of Curriculum and Instruction, Faculty of Education and Human Development, The Education University of Hong \\ Kong, Hong Kong SRA, China
}

Received February 6, 2020; Revised March 18, 2020; Accepted May 13, 2020

Copyright $\odot 2020$ by authors, all rights reserved. Authors agree that this article remains permanently open access under the terms of the Creative Commons Attribution License 4.0 International License

\begin{abstract}
This paper reports a quantitative study of psychological contract between employees and employers in the telecommunications industry in Hong Kong, and the relationships between the psychological contract, work behaviour and turnover intention. Previous research in the telecommunications industry in Hong Kong has focused mainly on consumer protection and telecommunications market competition, and research has seldom been done on the human resources is sues in this industry. This research investigates the informal relationship between employees and employers in the telecommunications industry in Hong Kong. A quantitative research methodology was used in this research by surveying emp loyees. A total of 227 valid responses were received, and the data was analysed by Partial Least Squares Structural Equation Modelling (PLS-SEM). The results found that the psychological contract has a significant relationship with work behaviour and turnover intention. The psychological contract is a better means of explaining turnover intention than work behaviour. Business managers can leverage this finding to develop better plans and approaches to deal with work behaviour and turnover intention is sues. The outcomes also provide empirical evidence to validate the psychological contract inventory developed by Rousseau [1]. This research contributes to the development of human resource theory and practice.
\end{abstract}

Keywords Psychological Contracts, Work Behaviour, Turnover Intention, Hong Kong Telecommunications Industry

\section{Introduction}

The deregulation of telecommunications services in
Hong Kong not only creates business opportunities for companies but also provides substantial career development opportunities for employees. The business growth of telecommunications services has established a strong workforce in this industry. However, based on the statistical information from the Office of Teleco mmunications Authority of Hong Kong (OFTA) [2], the total number of telecommunications full-time staff has fluctuated between 15,862 and 26,042 in the past decade in a declining trend. Staff turnover has been a common is sue encountered by telecommunications service providers in Hong Kong. Despite this, there has been little research on human resources issues in the industry, and previous research has focused mainly on consumer protection and telecommunications market competition. It is essential to investigate the relationship between the employer and employee and how it is affecting work behaviour and turnover intention.

Employee turnover has been a challenge for many organisations, in particular for human resources professionals [3]. It has been a critical organisational phenomenon that has attracted considerable managerial and scholarly attention for many decades [4]. Porter and Steers [5] argued that turnover has potentially critical consequences for both the person and the organisation. This study aims to investigate the relationship between the employee and employer in the telecommunications industry with regards to the psychological contracts involved, and also the relationship between the psychological contract, work behaviour and turnover intention. Lam [6] proposed effective retention strategies to tackle the turnover of the mailing staff in one of the largest telecommunications services operators after conducting an empirical study. To understand the relationship between the emp loyee and emp loyers, many scholars have proposed studying the psychological contract. A psychological 
contract is defined as "An individual's beliefs regarding the terms and conditions of a reciprocal exchange agreement between that focal person and another party" [7]. Previous research on the psychological contract has largely been undertaken in Western countries, so the results might not apply to Hong Kong given the cultural differences. The objective of the study is to deepen managers' and researchers' knowledge and understanding in psychological contracts so as to use them to formulate appropriate human resources strategies and plans.

\section{Literature Review}

The concept of the psychological contract can be traced back to the 1930s, and significant acade mic interest in it has grown since the late 1990s [8]. The psychological contract is an important research tool in organisational studies for understanding how the employee-organisation relationship is constituted and how it develops and changes, and for understanding the consequences of a breakdown in the relationship [9]. It is about the mutual expectations [10], the relationship between the rewards and the work performed [11], and the rights, privileges, and obligations between employee and employer [12]. This psychological relationship develops around the explicit process of co-operative exchanges that operate between an employee and an employer [13].

\subsection{Psychological Contract}

The psychological contract involves the employee receiving benefits such as pay, training and job security, in return for providing effort and contribution to the organisation [14]. Rousseau recognises the psychological contract as a particular type of promissory contract and, because it involved beliefs, it existed "in the eye of the beholder" [15]. It is important to have a healthy psychological contract to ensure a harmonious relationship between the employee and employer, and once violated by either party they no longer have a co mmon set of goals [16]. Rousseau [1] mentioned that researchers had proposed four different typologies including relational, balanced, transactional and transitional to conceptualise the forms of promissory contracts.

"Relational contracts are based on mutual trust and loyalty; it is a long-term or open-ended employment relationship. The rewards are deriving from membership and participation in the organisation and are only loosely conditioned on the performance of employees." [1, p. 4]. Rousseau [1] proposed two constructs to measure the relational contracts, they are stability and loyalty. Stability is a long-term employment relationship in which the employer commits to offering stable wages, and the emp loyee is obligated to do what is required to keep the job and remain with the firm. In loyalty contracts, the employees demonstrate that they are good organisational 'citizens': they are obligated to support the firm, manifest loyalty and commitment to the needs and interests of the organisation. In return, the employer is committed to supporting the wellbeing and interests of employees and their families.

"Balanced contracts are dynamic and open-ended employment arrangements, which are conditional on the economic success of the firm and employee opportunities to develop career advantages. Employee and employer make valuable contributions to each other with learning and development. The rewards to employees are performance-based, which can contribute to the firm's comparative advantages, particularly under the market pressure of changing demands", [1, p. 4]. There are three constructs proposed by Rousseau [1] to measure the balanced contracts, namely External Employability, Internal Advancement and Dynamic Performance. External employability measures the obligation to career development on the external labour market. The employee is obligated to develop their own skills which are demanded in the market, and the employer makes a commitment to enhance the employee's long-term employability whether it is inside or outside the organisation. Internal advancement measures the obligation to career development inside an organisation. The emp loyee has an obligation to develop their own skills which can be of value to their current employer, and the emp loyer has made a commitment to create internal career advancement opportunities for the employee. Dynamic performance measures the obligation to performance support. The employee is obligated to take up and perform well new and more demanding goals, which constantly change, in order to help the firm become and remain competitive. The employer is committed to providing continuous learning opportunities to help employees achieve their performance requirements.

"Transactional contracts are a short-term or limited time employment arrangement. They are primarily focused on the economic exchange that the employee's duties provide specific, narrow and only limited involvement in the organisation." [1, p. 4]. Rousseau [1] proposed two constructs to measure transactional contracts, namely Narrow and Short-term. Narrow measures the relationship between the employee and employer in a limited or fixed scope of duties. The employee is obligated and paid to perform only an agreed set of duties. The employer has committed to offering the employee only limited involvement in the organisation with little or no training and employee development opportunities. Short-term measures the relationship between the employee and employer in a specific and limited time. The employee basically has no obligation to remain with the firm and is committed to working only for a specific and limited time. The employer is not obligated to any future commitments.

"Transitional contracts are a cognitive state reflecting 
the consequences of organisational change and transition that are at odds with previously established employment arrangements." [1, p. 4]. Rousseau [1] proposed three constructs to measure transitional contracts, namely Mistrust, Uncertainty and Erosion. Mistrust measures the lack of trust between the employee and the employer. This is because the employee believes the organisation sends unclear, inconsistent and mixed information about its intentions. The employer does not trust its workers either, and withholds important information about the organisation. Uncertainty measures the relationship between the employee and employer in an environment of the ambiguity of obligation and future commitments. The employee is not clear about the nature of his or her own obligations to the firm and the employer evaluates the extent that the employee is uncertain regarding the employer's future commitments to him or her. Erosion measures the relationship between the employee and employer in a corrosive environment. The employee anticipates a declining of returns from his or her contributions to the firm compared to the past and the employer has introduced changes that reduce employee rewards, e.g. wages and benefits, eroding the quality of work-life compared to previously.

\subsection{Work Behaviour}

The concept of organisational citizenship behaviour (OCB) was introduced in the organisational research literature in the early 1980s [17]. Smith, Organ and Near [18] defined the last of these aspects as "Organisational Citizenship Behaviour" (OCB), and Organ [19] argued that OCB should be regarded as the most important of the three aspects of behaviour as it can promote the efficient and effective functioning of an organisation. This is because the sense of responsibility felt by employees can be expected to extend well beyond the job remit. OCB does influence the organisation's performance, as the available empirical evidence has indicated [20]. Kazt and Kahan [21] and Jex [22] argued that OCB is a form of productive behaviour that affects the organisation's effectiveness. Spector [23] also argued that OCB is an essential aspect of the employee's behaviour that can contribute to the overall effectiveness of the organisation. In research undertaken by Mackenzie, Podsakoff and Fetter [24], it was indicated that there was no positive correlation found between individual's performance and his/her OCB score; however, other research undertaken by Podsakoff, Ahearne and MacKen zie [25] found that group performances are correlated to the extent of the OCB.

With the growing interest in OCB, the constructs were expanded and diversified [26]. OCB can be categorised using two broad dimensions [18]: altruis $m$ and generalised compliance. In this research, these two dimensions are used to measure the OCB of the respondents. Altruism captures the direct and intentional behaviour in a specific face-to-face situation, such as orienting a new colleague, or helping a colleague with a heavy workload [18]. Podsakoff et al. [20, p516] defined altruis $\mathrm{m}$ as helping behaviour, following the work done by Organ [19], who defined altruis $m$ as a voluntary action that helps people to solve work problems, such as teaching new staff to use equipment, helping peers to clean up their work backlog, and searching for information for someone. Altruis $m$ is labelled as OCBI-behaviour and immediately benefits specific individuals, and indirectly through contributions to the organisation (e.g. covering for colleagues who are absent from their work) [27]. In this sense, altruism involves doing something extra to help supervisors or peers such as taking up the work of an absent co-worker [23]. General compliance "is doing what needs to be done and following rules, such as going to work on time and not wasting time" [23, p236]. Generalised compliance "pertains to a more impersonal form of conscientiousness that does not provide immediate aid to any one specific person, but rather is indirectly helpful to others involved in the system" [18, p 657]. The behaviour (e.g., punctuality, not wasting time) seems to represent something akin to compliance with internalised norms that define what a "good employee ought to do". Williams and Anderson [27, p601] labelled general compliance as the OCB-O dimension, behaviour that benefits the organisation in general (e.g. providing prior notice of absence from work, or following informal and self-defined rules to maintain order).

\subsection{Turnover}

Turnover refers to "employees both entering and leaving organisations" [28]. It is often implied that employees who leave an organisation do so on their own initiative rather than as a result of organisational decisions. It is "the cessation of membership in an organisation by an individual who received monetary compensation from the organisation" [29]. Turnover intention is related to the various informal relationships between the employee and employer. The informal relationships include job satisfaction [30], employee expectations from the employer for career development and working, opportunities for alternative employment, participation in job-related decisions, receiving job-related information, friendships with peers, the organisation's commitment, job nature [31], and working conditions [32]. All these informal relationships are highly relevant to the psychological contract model as proposed by Rousseau [1]. The respondents were observed to have moderate occupational and organisational commitment and low turnover intention [6]. 


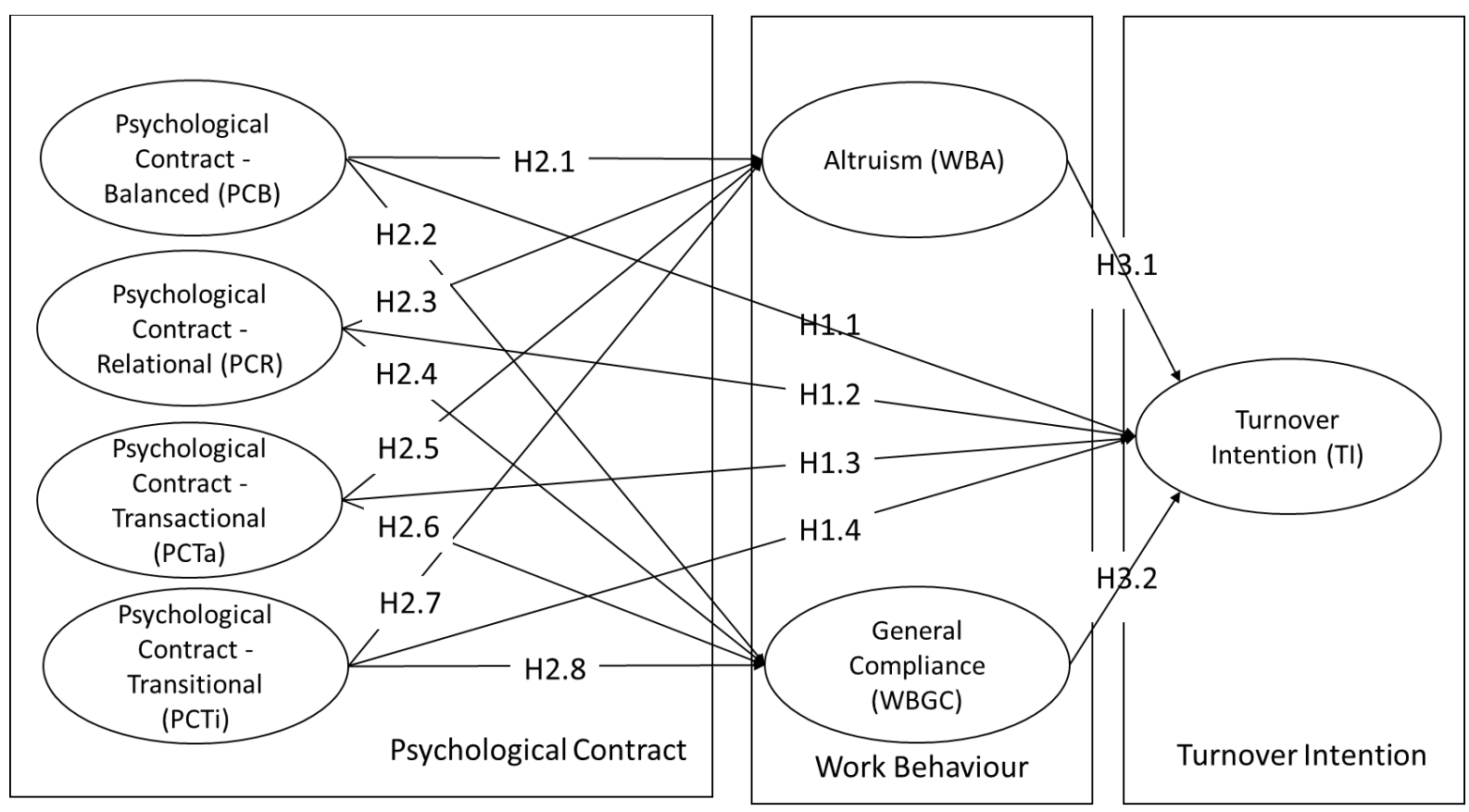

Figure 1. Conceptual Framework of this Study

\subsection{Conceptual Framework}

The conceptual framework consists of three main components, namely Psychological Contract, Work Behaviour and Turnover Intention (See Figure 1). The literature indicates that the psychological contract will lead to a positive or negative effect on work behaviour; and psychological contract commitment and work behaviour will lead to a turnover decision. Putting these three factors together in this study would provide a comprehensive view of their relationships and a better understanding of the consequences of psychological contracts, and how they affect the employees' work behaviour and their intention to leave the company. This research aims to answer the research questions - what is the relationship between psychological contract, work behaviour and turnover intention?

\section{Methods}

There were three main concept measures in this study: the Psychological Contract (PC), Work Behaviour (W B) and Turnover Intention (TI). Psychological contracts are described by the instruments developed by Rousseau [33], which measure both the employee and employer obligations. The description of work behaviour is based on the two dimensions of Organisational Citizenship Behaviour (OCB) proposed by Smith, Organ and Near [18, pp662-3], namely Altru ism and Generalised Compliance. TI is measured using the instrument created by Mobley, Horner and Hollingsworth [34]. This instrument uses three items: thinking of quitting, intention to search for other employment, and intention to quit the present job.
The Psychological Contract was measured by four constructs, namely Psychological Contract - Balanced (PCB), Psychological Contract - Relational (PCR), Psychological Contract - Transactional (PBTa), and Psychological Contract - Transitions (PCTi). Work Behaviour is referred to as Organisational Citizenship Behaviour (OCB) within this research and was measured by two constructs namely Work Behaviour - Altruism (WBA) and Work Behaviour - Generalised Compliance (WBGC). TI had only one construct. All variables were measured by using a five-point Likert-scale in which 1 was "Not at all", 2 was "Slightly", 3 was "So mewhat", 4 was "Moderately", and 5 was "To a great extent".

The questionnaire was carefully designed based on the suggestions of Ticehurst and Veal [35] and Frazer and Lawley [36] who recommend that jargon, leading questions and ambiguities be avoided. The survey was carried out using a self-adminis trated questionnaire with a target sample size of 200 . The data was prepared in three interactive steps: data entry, data editing and data coding. The target respondents were employees in the telecommunications industry in Hong Kong. Bayesian approach is applied to determine the appropriate sample size with $\mathrm{N}_{0}=\mathrm{t}^{2} \mathrm{x} \mathrm{s}^{2} / \mathrm{d}^{2}$. Where $\mathrm{t}=1.96$ for 0.05 alpha level, $s=0.833$ for 5-point scale and 6 standard deviations, $\mathrm{d}=0.15$ for 5-point scale and 0.03 marg in of error. Therefore the minimum sampling size is 118 . The targeted sampling size for this research is 200 .

\section{Findings}

There were a total of 235 questionnaires returned, and 227 were valid. The respondents were mostly aged 40- to 
49-years-old (35.3\%); female (60\%); married $(56.5 \%)$; holding a Bachelor's degree (42.3\%); working at officer/senior officer level (34.7\%); working in sales and marketing areas $(30.2 \%)$; having 15 to 20 years working experience; and 1 to 5 years working in their current organisation. The respondents' organisations were largely providing mobile services ( $44.2 \%$ ); had more than 15 years' industry experience (32.4\%) the size of the companies comprised 1000 to 1999 staff (22.6\%); and more than half were private companies $(52.7 \%)$.

The validity and reliability of each construct was assessed using exploratory factor analysis (EFA) and Cronbach's Alpha Coefficients respectively. Normality was checked to determine if any transformation was required prior to performing multivariate analysis. Principal components analysis (PCA) and Pearson Correlations were used in EFA. The assessment was done based on the suggestions by Hair et al. [37] that the item-to-item correlations in PCA should exceed 0.3, the item-to-total correlations in PCA should exceed 0.5, and there should only be one eigenvalue greater than 1 and the loading factors are all $>0.5$. In the exploratory study, values of $>0.6$ were considered acceptable for the Cronbach's Alpha coefficient. In the main study, Cronbach's Alphas $>0.7$ were considered acceptable, $>0.8$ were considered good and $>0.9$ were considered to be of excellent reliability [37 $\mathrm{p} 118$ ].

Hair et al. [38] suggested evaluating the collinearity issues of the structural model before proceeding with any analysis. The high collinearity can lead to incorrect estimation of the weights and their statistical significance. To assess the level of collinearity, Hair et al. [38] suggested calculating the tolerance (TOL), which represents the amount of variance of the formative indicator not exp lained by the other indicators in the same model. A related measure of collinearity is the variance inflation factor (VIF), which is defined as the reciprocal of the TOR. The
VIF value of 5 represents $80 \%$ of its variance, which is accounted for by the remaining formative indicators associated with the same construct. When the VIF is higher than 5 , the suggestion is to consider removing one of the corresponding indicators if it still sufficiently captures the content of the construct from a theoretical perspective [38]. In this research, the VIF of the inner model was checked, and all values are below the threshold 5; therefore, the collinearity among the predictor's constructs is not a critical issue, and we can continue the examination of the results.

Gefen, Straub and Boudreau [39] argued that the model of fit for a PLS model be established with the acceptability of high $\mathrm{R}^{2}$ values, with significant path coefficients. Hair et al. [38] suggested calculating the standard bootstrap error, which means computing the empiricalt values and $p$ values for the assessment. The coefficient is statistically significant at a certain error probability when it is larger than the critical value. In this research, $5 \%$ significant level is assumed, the critical is 1.96 for a two-tailed test. In this model, the $\mathrm{R}^{2}$ for Turnover Intention (TI) is 0.53 , Work Behaviour - Altruis m (W BA) is 0.62, and Work Behaviour - Generalised Compliance (WBGC) is 0.23 . The $t$ values and $\mathrm{p}$ values are reported in Table 1 and the paths with $p>0.05$ are found significant. In addition to assessing the R2 values, Hair et al. [38] suggested reporting the effect size $f^{2}$ of the endogenous constructs. The effect size $f^{2}$ is to measure the impact of the change in the $\mathrm{R}^{2}$ when a specified exogenous construct is omitted from the model. Cohen [40] mentioned that the $f^{2}$ with a value of $0.02,0.15$ and 0.35 represent small, moderate, and substantial effects. In this research, the $f^{2}$ values were calculated by SmartPLS. In the research, the effect size $f^{2}$ for the significant paths is between small to medium; whereas PCB to WBA has the large $f^{2}$ values (0.32), which is between medium to large effect, and the remaining paths with small $\left(0.02<f^{2}\right)$ to medium effect $(0.02<$ f $2<0.15)$.

Table 1. The SmartPLS analysis

\begin{tabular}{|c|c|c|c|c|c|c|c|c|}
\hline & Path & \begin{tabular}{|l|} 
Path \\
Coefficient \\
\end{tabular} & $\begin{array}{l}\text { Sample } \\
\text { Mean }(\mathrm{M}) \\
\end{array}$ & \begin{tabular}{|l|}
$\begin{array}{l}\text { Standard Deviation } \\
\text { (STDEV) }\end{array}$ \\
\end{tabular} & $\begin{array}{|lr|}\text { T } & \text { Statistics } \\
(\mid \mathrm{O} / \mathrm{ST} \text { DEV } \mid) \\
\end{array}$ & $P$ Values & \begin{tabular}{|l|} 
Significant \\
$(\mathrm{p}<0.05) ?$ \\
\end{tabular} & $f^{2}$ Values \\
\hline H1.1 & PCB -> TI & 0.25 & 0.25 & 0.10 & 2.50 & 0.01 & Yes & 0.03 \\
\hline H1.2 & PCR -> TI & -0.35 & -0.36 & 0.10 & 3.72 & 0.00 & Yes & 0.07 \\
\hline H1.3 & РCTa -> TI & -0.36 & -0.36 & 0.08 & 4.39 & 0.00 & Yes & 0.10 \\
\hline $\mathrm{H} 1.4$ & PCTi-> TI & -0.2 & -0.20 & 0.07 & 2.78 & 0.01 & Yes & 0.04 \\
\hline $\mathrm{H} 2.1$ & PCB -> WBA & 0.55 & 0.56 & 0.06 & 8.99 & 0.00 & Yes & 0.32 \\
\hline $\mathrm{H} 2.2$ & PCB -> WBGC & 0.28 & 0.28 & 0.11 & 2.62 & 0.01 & Yes & 0.04 \\
\hline $\mathrm{H} 2.3$ & PCR -> WBA & 0.11 & 0.11 & 0.07 & 1.61 & 0.11 & No & 0.01 \\
\hline $\mathrm{H} 2.4$ & PCR -> WBGC & -0.09 & -0.09 & 0.10 & 0.89 & 0.37 & No & 0.00 \\
\hline $\mathrm{H} 2.5$ & PCTa $\rightarrow$ WBA & 0.14 & 0.14 & 0.07 & 2.02 & 0.04 & Yes & 0.02 \\
\hline $\mathrm{H} 2.6$ & PCTa -> WBGC & 0.14 & 0.14 & 0.10 & 1.46 & 0.14 & No & 0.01 \\
\hline $\mathrm{H} 2.7$ & PCTi $->$ WBA & 0.05 & 0.05 & 0.06 & 0.90 & 0.37 & No & 0.00 \\
\hline $\mathrm{H} 2.8$ & PCTi -> WBGC & 0.22 & 0.22 & 0.07 & 2.97 & 0.00 & Yes & 0.03 \\
\hline $\mathrm{H} 3.1$ & WBA $->$ TI & 0.18 & 0.18 & 0.08 & 2.39 & 0.02 & Yes & 0.03 \\
\hline $\mathrm{H} 3.2$ & WBGC -> TI & -0.06 & -0.06 & 0.06 & 1.03 & 0.30 & No & 0.01 \\
\hline
\end{tabular}




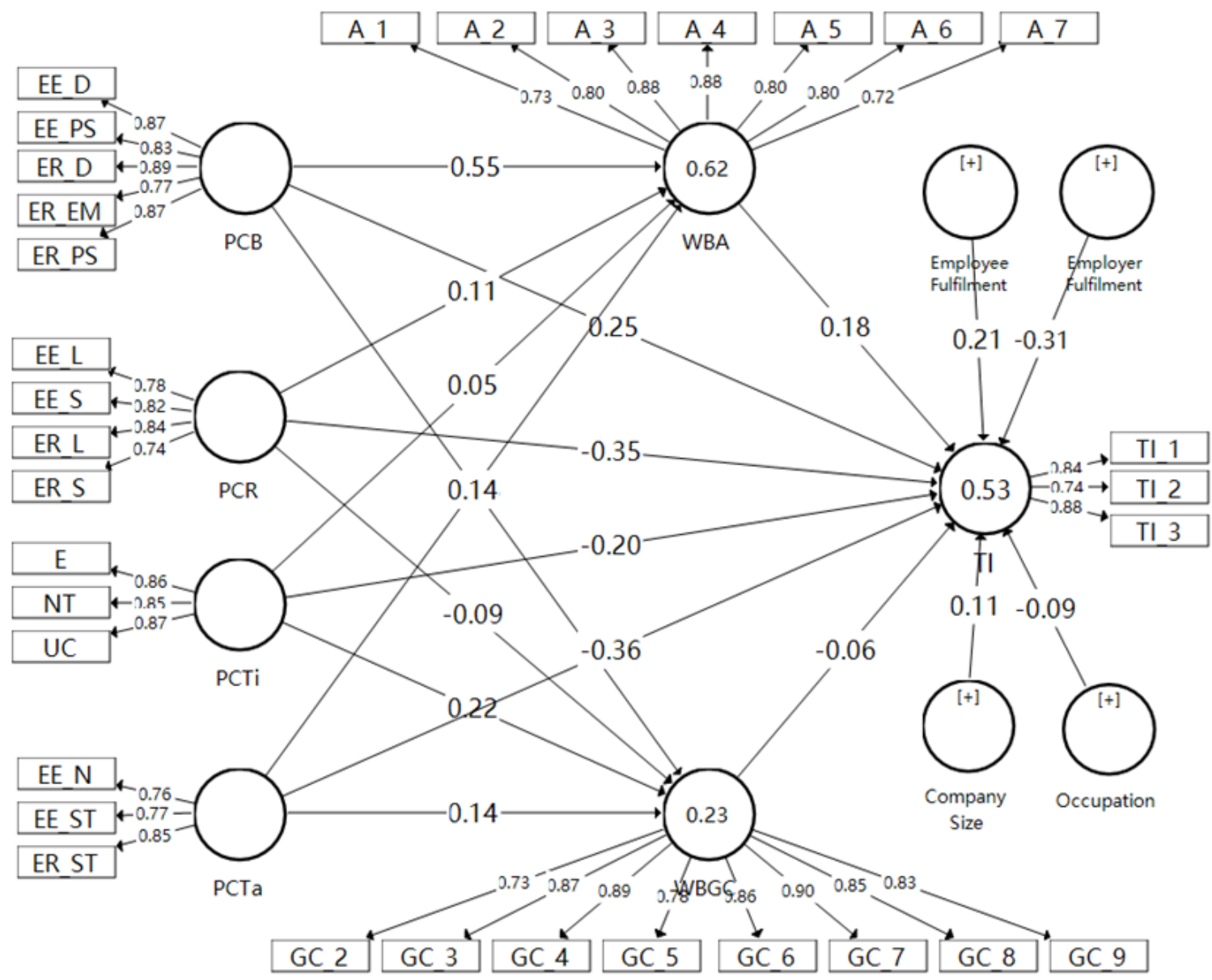

Figure 2. PLS-SEM of the study

The results from the SmartPLS analysis for the hypothesis test is as shown in Table 1 and Figure 2. The sub-hypothesis H1.1 tested the relationship between the Psychological Contract Balanced (PCB) and Turnover Intention (TI) with a path coefficient $0.25(t=2.5, p=0.01)$, even the path was statistical significant, this hypothesis was not supported as the path coefficient is a positive number, which implies a positive correlation instead of a negative correlation.

The sub-hypothesis H1.2 tested the relationship between Psychological Contract Relational (PCR) and Turnover Intention (TI) with a path coeffic ient $-.35(t=3.72, p=0.00)$, this result supports our hypothesis of a negative relationship between the Psychological Contract Re lational (PCR) and Turnover Intention (TI).

The sub-hypothesis H1.3 tested the relationship between Psychological Contract Transactional (PCTa) and Turnover Intention (TI) with a path coefficient -0.36 $(t=4.39, p=0.00)$. Since the questions for PCTa were asked in a reverse direction and the items were reverse transformed during the data preparation as discussed, the negative path coefficient is representing a positive correlation. This result supports our hypothesis of a positive relationship between the Psychological Contract
Transactional (PCTa) and Turnover Intention (TI).

The sub-hypothesis H1.4 tested the relationship between Psychological Contract Transitional (PCTi) and Turnover Intention (TI) with a path coefficient $-0.2(\mathrm{t}=3.78, \mathrm{p}=0.01)$. Since the questions for PCTi were asked in a reverse direction and the items were reverse transformed during the data preparation, the negative path coefficient is representing a positive correlation. This supports our hypothesis of a positive relationship between Psychological Contract Transitional (PCTi) and Turnover Intention (TI).

The sub-hypothesis $\mathrm{H} 2.1$ tested the relationship between the Psychological Contract Balanced (PCB) and Work Behaviour - Altruis m (WBA) with a path coefficient of $0.55(\mathrm{t}=8.99, \mathrm{p}=0.00)$. This result supports our hypothes is of a positive relationship between Psychological Contract Balanced (PCB) and Work Behaviour - Altruism (WBA).

The sub-hypothesis H2.2 tested the relationship between the Psychological Contract - Balanced (PCB) and Work Behaviour-Generalised Compliance (W BGC) with a path coefficient of $0.28(t=2.62, p=0.04)$. This result supports our hypothesis of a positive relationship between Psychological Contract - Balanced (PCB) and Work Behaviour - Generalised Compliance (WBGC) as $\mathrm{p}<0.05$, 
which is statistically significant.

The sub-hypothesis $\mathrm{H} 2.3$ tested the relationship between Psychological Contract - Relational (PCR) and Work Behaviour - Altruis m (WBA) with a path coefficient of $0.11(\mathrm{t}=1.61, \mathrm{p}=0.11)$. This result does not support our hypothesis of a positive relationship between the Psychological Contract - Relational (PCR) and Work Behaviour - Altruism (WBA) as $\mathrm{p}>0.05$, which is statis tically not significant.

The sub-hypothesis $\mathrm{H} 2.4$ tested the relationship between Psychological Contract - Relational (PCR) and Work Behaviour - Generalised Compliance (W BGC) with a path coefficient of $-0.09(t=0.89, p=0.37)$. This result does not support our hypothesis of a positive relationship between the Psychological Contract - Relational (PCR) and Work Behaviour - Generalised Compliance (WBGC) as $\mathrm{p}>0.05$, which is statistically not significant.

The sub-hypothesis $\mathrm{H} 2.5$ tested the relationship between Psychological Contract -Transactional (PCTa) and Work Behaviour - Altruis m (WBA) with a path coefficient of $0.14(t=2.02, p=0.1)$. Since the questions for PCTa were asked in a reverse direction and the items were reverse transformed during the data preparation, the positive path coefficient is representing a negative correlation. This result supports our hypothesis of a negative relationship between the Psychological Contract - Transactional (PCTa) and Work Behaviour - Altruism (WBA).

The sub-hypothesis $\mathrm{H} 2.6$ tested the relationship between Psychological Contract - Transactional (PCTa) and Work Behaviour - Generalised Compliance (W BGC) with a path coefficient of $0.14(\mathrm{t}=1.46, \mathrm{p}=0.14)$. This result does not support our hypothes is of a negative relationship between the Psychological Contract - Transactional (PCTa) and Work Behaviour - Generalised Compliance (WBGC) as the $p>0.05$, which is statistically not significant.

The sub-hypothesis $\mathrm{H} 2.7$ tested the relationship between Psychological Contract - Transitional (PCTi) and Work Behaviour - Altru is m (W BA) with path coefficient of 0.05 $(t=0.90, p=0.37)$. Since the questions for PCTi were asked in a reverse direction and the items were reverse transformed during the data preparation, the positive path coefficient is representing a negative correlation. Nevertheless, this result does not support our hypothes is of a negative relationship between Psychological Contract Transitional (PCTi) and Work Behaviour - Altru ism(W BA) as the $\mathrm{p}>0.05$, which is statistically not significant.

The sub-hypothesis $\mathrm{H} 2.8$ tested the relationship between Psychological Contract - Transitional (PCTi) and Work Behaviour - Generalised Compliance (WBGC) with a path coefficient of $0.22(t=2.97, p=0.00)$. Since the ques tions for PCTi were asked in a reverse direction and the items were reverse transformed during the data preparation, the positive path coefficient is representing a negative correlation. This result supports our hypothesis of a negative relationship between Psychological Contract Transitional (PCTi) and Work Behaviour Generalised
Compliance (WBGC).

Sub-hypotheses H3.1 tested the relationship between the Work Behaviours Altruism (WBA) and Turnover Intention (TI). The result indicates that the path coefficient was 0.18 $(t=2.39, p=0.02)$. The hypothes is was rejected as the path coefficient was a positive value even it is statistically significant $(\mathrm{p}<0.05)$.

Sub-hypothesis H3.2 tested the relationship between the Work Behaviours Generalised Compliance (WBGC) and Turnover Intention (TI). This result rejects the hypothes is of a negative relationship between these two variables as the path coefficient was $-0.06(\mathrm{t}=1.03, \mathrm{p}=0.3)$, which is statistically not significant.

\section{Discussions}

The psychological contracts (in terms of balanced and transactional) positively influence the employee's work behaviours in terms of altruism. It also positively influence the employee's work behaviours in terms of generalised compliance. There is no significant relationship between work behaviours and turnover intention found; and the relationships between psychological contacts and turnover intention are mainly a direct effect, only the employee's work behaviour in terms of altruis $m$ has a partial competitive mediation effect between balanced psychological and turnover intention. Psychological contract, co mpared with work behaviour, is a better predictor of turnover intention. Three out of four types of psychological contracts having a significant relationship with turnover intention.

A negative correlation was found between the balanced psychological contact and the turnover intention, and a negative correlation was found between the relational psychological contract and the turnover intention [41, 42, $43,44,45,46,47]$ and that the binding of the transitional and transactional psychological contract can have a positive correlation with the turnover intention [43, 48, 49]. Such findings were also supported by the research undertaken by Larwood, Wright, Desrochers and Dahir [50], Freese and Schalk [51], Tekleab and Tay lor [52] and Meyer \& Allen [53].

This research echoed the findings of the previous research, such as Kotter [54], Robinson [55], Shore and Barksdale [56], Turnley and Feldman [57], Lester and Kickul [58], Sutton and Griffin [59], and Lemire and Rouillard [60], related to the relationship between the psychological contract and turnover intention. Turnley and Feldman [57] demonstrated from their research that any negative factors perceived by the employees with regards to non-fulfilment of the psychological contract, lead the individual to have a greater intention to quit in order to escape the perceived work environ ment. [50] also confirmed from their research that non-fulfilment of the psychological contract was associated with a greater 
expressed intention by employees to quit their current jobs. This finding is also supported by others scholars, e.g. Freese and Schalk [51] and Tekleab and Taylor [52].

Rousseau [1] classified the relational psychological contract as a long-term and open-ended employment relationship, the transactional psychological contract as a short-term or limited time employment relationship, and the transitional psychological contract, which influences the previously established employment arrangement, as a cognitive state reflecting the consequence of organisational change. These three types of psychological contract have significant influence on the employee's turnover intention. This implies that the organisation has to carefully manage the informal relationship between the employee by improving the communication to remove mistrust and uncertainty, it will definitely help with respect to assisting staff retention.

In this research, work behaviour was measured by Organisational Citizenship Behaviour [18] in which there are two constructs, namely Work Behaviour - Altruism (WBA) and Work Behaviour - Generalised Compliance (WBGC). For the psychological contract, the same constructs were used in $\mathrm{H} 1$ as proposed by Rousseau [1]. There are a total of eight sub-hypotheses, and these were divided into two groups. The first group (H2.1, H2.3, $\mathrm{H} 2.5$ \& H2.7) tests the relationship between the four types of psychological contract with work behaviour in terms of altruis $m$ while the second group (H2.2, H2.4, H2.6 \& $\mathrm{H} 2.8$ ) tests the relationship between the four types of psychological contract with work behaviour in terms of generalised compliance.

For the relationship with Work Behaviour - Altruism (WBA), it is found that $\mathrm{H} 2.1$ (balanced psychological contract) and $\mathrm{H} 2.5$ (transactional psychological contract) were supported, while H2.3 (relational psychological contract) and H2.7 (transitional psychological contract) were rejected. For H2.1, the path coefficient between Psychological Contract - Balanced (PCB) and Work Behaviour - Altru ism (WBA) was $0.55(\mathrm{t}=8.99, \mathrm{p}=0.00)$ and for $\mathrm{H} 2.5$ the path coefficient between the Psychological Contract - Transactional (PCTa) and Work Behaviour - Altru ism (WBA) was $0.14(\mathrm{t}=2.02, \mathrm{p}=0.04)$. This implies a higher obligation from employee and employer to improve training, internal career advancement and external employability opportunities would lead to the employee being more willing to offer help in the organisation to other colleagues, e.g., providing orientation to a new colleague and helping a colleague with a heavy workload [18]. The short-term relationship with limited or fixed scope of duties or a specific or limited time would lead the employee to be less willing to offer help in the organisation. The results of $\mathrm{H} 2.3$ and $\mathrm{H} 2.7$ indicated that there was no significant relationship existing and the path coefficient was also comparatively low. However, it is recommended that the organisation should also take notice of the potential impacts on work behaviours from these two types of informal relationship with the employee. This is because such findings may be specific to the telecommunication industry in Hong Kong, so the interpretation of the results should only be applied in this context unless we can demonstrate generalised behaviours in future research. Based on the definition, the relational psychological contract represents a long-term and open-ended relationship[1], which is often in the form of job security. Indeed, Staufenbiel and Konig [61] argued that job insecurity will have a negative impact on work performance, so the employer must make an effort to build a good relationship with the employee by removing mistrust and uncertainty to create a shared understanding working environment [43].

For the second group of hypotheses (H2.2, H2.4, H2.6 $\& \mathrm{H} 2.8$ ) re lating to the relationship between the four types of psychological contract and work behaviour in terms of generalised compliance, the results indicated that $\mathrm{H} 2.2$ and $\mathrm{H} 2.8$ were supported and $\mathrm{H} 2.4$ and $\mathrm{H} 2.6$ were rejected. For H2.2, the path coefficient between the Psychological Contract - Balanced (PCB) and Work Behaviour Generalised Compliance (WBGC) was $0.28 \quad(\mathrm{t}=2.62$, $\mathrm{p}=0.01$ ), and for $\mathrm{H} 2.8$, the path coefficient between the Psychological Contract - Transitional (PCTi) and Work Behaviour - Generalised Compliance (WBGC) was 0.22 $(t=2.97, \quad p=0.00)$. The path coefficients were not particularly high, but there was a significant relationship. The definition of work behaviour in terms of generalised compliance refers to "a more impersonal form of conscientiousness that does not provide immediate aid to any one specific person, but rather is indirectly helpful to others involved in the system" (17, p657). It focuses more on individual-level behaviours, e.g. punctuality, not wasting time and self-defined rules to maintain order as stated by Williams and Anderson (17, p601). The results of the hypotheses test imply that the higher obligation by both employee and employer to work on training and career development (balanced psychological contract) together with efforts to remove mistrust and uncertainty (transitional psychological contract) will lead to the employee having better work behaviours, which can also help the organisation to build a good corporate culture. It is noticed that $\mathrm{H} 2.4$ and $\mathrm{H} 2.6$ were not supported as the paths are not statistically significant. The path coefficient between the Psychological Contract - Relational (PCR) and Work Behaviour - Generalised Compliance (WBGC) was $0.11(\mathrm{t}=1.61, \mathrm{p}=0.11)$ and the path coefficient between the Psychological Contract - Transactional (PCTa) and Work Behaviour - Generalised Compliance (WBGC) was $0.14(\mathrm{t}=1.46, \mathrm{p}=0.14)$. However, it is recommended that the organisation not underestimate the potential impacts of such relations even though no significant relations were supported by the collected data. As is discussed in previous paragraphs, the transactional psychological contract does influence the OCB in term of 
altruis $m$. Such easy-to-exist agreement does influence the employee when it comes to offering help to other employees. The four types of psychological contact and the two aspects of OCB are interdependent and form a complex web of exchanges between employees and employer [62, p124]. The psychological contract is a dynamic relationship and, given that multiple psychological contracts exist, the organisation should manage them as a meta-contract across the firm [62].

This research echoed the findings of previous research $[63,64,65,66]$ on the relationship between the psychological contract and work behaviour given that significant relationships were found. These studies found that negative emotions are a likely consequence of an undesirable psychological contract. Undesirable psychological contracts also impact on workplace effectiveness [66, p669], while emp loyees' perceptions of politics and procedural justice influence their psychological contracts, work attitudes and contextual performance in terms of Organisational Citizenship Behaviour [65, p213]. Employees who are highly committed show less destructive behaviour and attempt more constructive behaviour [63, p596]. Harrison, Neuman and Roth found that work-related attitudes are related to the employee's contributions to his or her work role.

There were two sub-hypotheses proposed to test the relationship between work behaviour in terms of altruism (H3.1) and work behaviour in terms of generalised compliance (H3.2) with turnover intention. The results from the data analysis rejected both hypotheses. For H3.1, the path coefficient between the Work Behaviours Altruism (WBA) and the Turnover Intention (TI) were $0.22(\mathrm{t}=2.6, \mathrm{p}=0.01)$, even though statistically significant, is positive, which implied a positive correlation instead of a negative correlation. For H3.2, the path coefficient between the Work Behaviours - Altruis m (BWA) and Turnover Intention (TI) were $-0.09(\mathrm{t}=1.47, \mathrm{p}=0.14)$ was not statistically significant, therefore, the hypothesis was rejected.

This research did not echo the findings in previous research by Chen and Wei [67, p8] and Khalid et al. [68, p112] which found that a significant relationship between work behaviour and turnover intention existed and that work behaviour and turnover intention were negatively correlated. This finding seems to contradict our understanding of previous literature; therefore, an additional analysis was conducted to evaluate the relationship between work behaviours with turnover intention alone. The result indicated that both Work Behaviour - Altruis m (WBA) and Work Behaviours Generalised Compliance (WBGC) have a significant negative correlation with Turnover Intention (TI). These results aligned with our understanding of the previous literature, despite the fact it was noticed that the $R^{2}$ is just 0.15 , which means that only $15 \%$ of turnover intention can be explained by work behaviour. The previous research undertaken by Castro, Armario and Ruize [69], Chen and Wei [67], Mossholder, Settoon \& Henagan [70], Khalid et al. [68], and Chen, Hui and Sego [71] demonstrated a significant relationship with a low to moderate effect. Therefore, the employer must pay special attention to managing the employees' informal work behaviour. The individual will increase their tendency to withdraw from his/her job when his/her OCB at work decreases. OCB was high when employees have no turnover intention.

\section{Conclusions}

The study found that the psychological contract between employers and employees has a significant impact on work behaviour and turnover intention. It was also found that the psychological contract is a better means of explaining turnover intention than work behaviour. The findings of this research provide a better understanding of the psychological contract between employees and employers in the telecommunications industry in Hong Kong. Business managers can leverage this finding to develop better plans and approaches to deal with work behaviour and turnover intention is sues. The outcomes also provide empirical evidence to validate the psychological contract inventory developed by Rousseau [1] for the telecommunications industry in Hong Kong. This research fills a knowledge gap in this area and also provides a solid foundation for future research.

\section{Implications}

To better manage the psychological contract, employers should understand individual differences and perceptions about employee commitment versus employer commitment in order to align the individual goals with the organisation goals. Human resources policy and practice should be able to address individual needs, to support their needs in order for them to perform well in their current roles, provide internal promotion opportunities, provide necessary training opportunities to enable them to take up new roles in the organisation, and provide necessary training for employees to acquire the necessary skills and knowledge, which are externally recognised, e.g. professional bodies and other employers. Employers should improve communication with employees such that they can have a better understanding of the strategic direction, goals and objectives of the company. This has the potential to improve mistrust and uncertainty. They should make use of the psychological contract inventory (e.g. the instrument used in this research, as developed by Rousseau [1] as a management tool for psychological contract measurement. Finally, they should establish psychological contract management, which includes four steps: Measure, Identify, Act and Check. The Measure 
relates to surveying the perception of the psychological contract between employee and employer. Identify relates to finding out the areas that can improve the psychological contract. Act relates to implementing an action plan to improve the psychological contract, while Check relates to reviewing if the implemented action can achieve the desired results or not. This is a continual process to help the organisation to find out the strengths and gaps in the psychological contract between the employee and employer, to find out the core areas of improvement, and to keep track of the actions taken. The output of the psychological contract manage ment process should fit into the overall Human Resources policy and planning.

\section{REFERENCE}

[1] Rousseau, D. M.. Psychological Contract Inventory Technical Report, Carnegie Mellon University; 2000. Pittsburgh, USA.

[2] OFTA, Telecommunication Indicators in Hong Kong for Fiscal Years 1993/94 to 2010/11, 2012. OFTA HKSAR, viewed Apri $52012<$ http://tel_archives.ofca.gov.hk/en/dat astat/hktelecom-indicators_summary.html $>$

[3] Blau, G. Further Exploring the Relationship between Job Search and Voluntary Individual Turnover. Personnel Psychology, 1993; vol. 46, no. 2, pp.313-30.

[4] Hom, P. \& Graffeth, R., Employee Turnover, South-Western Series in Human Resource Management, South-Western Colleage Pub., 1995. Cincinnati, Ohio.

[5] Porter, LW \& Steers, RM, 'Organizational, Work and Personal Factors in Employee Turnover and Absenteeism', Psychological Bulletin, 1973. vol. 80, no. 2, pp. 151 - 76.

[6] Lam, SC, 'Empirical Study of Part Time Staff Turnover in the Mailing Function of Hong Kong Telecom', MBA thesis, 1998. The Hong Kong Polytechnic University.

[7] Rousseau, DM, 'Psychological and Implied Contracts in Organizations', Employee Responsibilities and Rights Journal, 1989. vol. 2, no. 2, pp.121-39.

[8] O'Donohue, W, 'Professional Ideology and the Psychological Contract: An Analy sis of the Psychological Contracts of Registered Nurses, Research Scientists and Primary School Teachers Employed in Public Sector Organisations', 2007. University of Tasmania.

[9] Taylor, S \& Tekleab, AG, 'Taking Stock of Psychological Contract Research: Assessing Progress, Addressing Troublesome Issue, and Setting Research Priorities', 2004. in JAM Coyle-Shapiro,

[10] LM Shore, MS Taylor \& L Tetrick, E. (eds), The Employment Relationship: Examining Psychological and Contextual Perspectives, New York: Oxford; pp. 253 - 83.

[11] Guest, 'The Psychology of the Employment Relationship: An Analysis Based on the Psychological Contract', Applied Psychology: An International Review. 2004; vol. 53, no. 4, pp. 541-55.
[12] Levinson, H, Price, C, Munden, K \& Solley, C. Men, Management, and Mental Health. Cambridge, MA: Harvard University Press; 1962.

[13] Schein, E. Organisational Psychology. Englewood-Cliffs, NJ: Prentice-Hall; 1965.

[14] Barnard, CI. The Functions of the Executive. Cambridge, MA: Harvard University Press; 1938.

[15] Newell, H \& Dopson, S. 'Muddle in the Middle: Organizational Restructuring and Middle Management Careers'. Personnel Review. 1996; vol. 25, no. 4, pp.4-20.

[16] Rousseau, DM \& McLean Parks, J. 'The Contracts of Individuals and Organizations'. Research in Organizational Behaviour. 1993; vol. 15, no. 1, pp.1-43.

[17] Armstrong, M. A Handbook of Human Resource Management Practice. London, UK: Kogan Page; 1996. 10 edn.

[18] Bateman, TS \& Organ, DW. 'Job Satisfaction and the Good Soldier: The Relationship between Affect and 'Citizenhsip". Academy of Management Journal. 1983; vol. 26, no. 4, pp. 587-95.

[19] Smith, CA, Organ, DW \& Near, JP. 'Organizational Citizenship Behavior: Its Nature and Antecedents'. Journal of Applied Psychology. 1983; vol. 68, no. 4, pp.653-63.

[20] Organ, DW., Organizational Citizenship Behavior: The Good Soldier Syndrome, Organization and Management. Lexington, Mass: Lexington Books; 1988.

[21] Podsakoff, PM, MacKenzie, SB, Paine, JB \& Bachrach, DG. 'Organizational Citizenship Behaviors: A Critical Review of the Theoretical and Empirical Literature and Suggestions for Future Research'. Journal of management. 2000; vol. 26, no. 3, pp. 513-63.

[22] Katz, D \& Kahn, RL. The Social Psychology of Organizations. New York: John-Wiley; 1978. 2nd edn.

[23] Jex, SM. Organizational Psychology: A Scientist-Practioner Approach. New York, USA: John Wiley \& Son:, 2002.

[24] Spector. Industrial \& Organizational Psychology; Research and Practice. New York: John Wlley \& Sons, Inc; 2000, 2 edn.

[25] Mackenzie, SB, Podsakoff, PM \& Fetter, R. 'Organizational Citizenship Behavior and Objective Productivity as Determinants of Managerial Evaluations of Salespersons' Performance'. Organizational Behavior and Human Decision Processes. 1991; vol. 50, no. 1, pp. 123-50.

[26] Podsakoff, PM, Ahearne, M \& Mackenzie, SB. 'Organizational Citizenship Behavior and the Quantity and Quality of Work Group Performance'. Journal of Applied Psychology. 1997; vol. 82, no. 2, pp. 262-70.

[27] Kim, S. 'Public Service Motivation and Organizational Citizenship Behavior in Korea'. International Journal of Manpower. 2006; vol. 27, no. 8, pp. 722-40.

[28] Williams, LJ \& Anderson, SE. 'Job-Satisfaction and Organizational Commitment as Predictors of Organizational Citizenship and in-Role Behaviors'. Journal of management. 1991; Vol. 17, no. 3, pp.601-17. 
[29] Bluedorn, AC. 'A Taxonomy of Turnover'. Academy of Management Review. 1978; vol. 3, no. 3, pp.647-51.

[30] Mobley. Employee Turnover: Causes, Consequences and Control. Reading, MA: Addison-Wesley; 1982.

[31] Mobley, WH, Griffeth, RW, Hand, HH \& Meglino, BM., 'Review and Conceptual Analysis of the Employee Turnover Process'. Psychological Bulletin. 1979; vol. 86, no. 3, pp. 493-522.

[32] Steers, RM \& Mowday, RT., 'Employee Turnover and Post Decision Accommodation Processes', in L Cummings \& B Staw (eds), Research in Organizational Behavior, Greenwich, CT: JAI Press; 1981. pp. 235 - 81.

[33] Hulin, CL, Roznowski, M \& Hachiya, D. 'Alternative Opportunities and Withdrawal Decisions - Empirical and Theoretical Discrepancies and an Integration'. Psychological Bulletin. 1985; vol. 97, no. 2, pp. 233-50.

[34] Rousseau, DM. Psychological Contracts Inventory, Pittsburgh, USA: Carnegie Mellon University;2008.

[35] Mobley, W, Horner, S \& Hollingsworth, A. 'An Evaluation of Precursors of Hospital Employee Turnover'. Journal of Applied Psychology. 1978; vol. 63, no. 4, pp. 408-14.

[36] Ticehurst, G \& Veal, A. Business Research Methods: A Managerial Approach. South Melbourne: Addison Wesley Longman; 2000.

[37] Frazer, L \& Lawley, M. Questionnaire Design and Administration: A Practical Guide. Brisbane: John Wiley \& Sons Australia, Ltd; 2000.

[38] Hair, JF, Anderson, RE, Tatharn, RL \& Black, WC., Multivariate Data Analysis. New Jersey: Prentice-Hall; 1998, 5 edn.

[39] Hair, JF, Hult, GTM, Ringle, CM \& Sarstedt, M. A Primer on Partial Least Squares Structural Equation Modelling (Pls-Sem), Los Angeles: SAGE; 2017, 2nd Edition edn.

[40] Gefen, D, Straub, DW \& Boudreau, M. Structural Equation Modelling and Regression: Guidelines for Research Practice. Communications of the Association for Information Systems Management. 2000; vol. 4, no. 7, pp $1-70$.

[41] Cohen, J.. Statistical power analysis for the behavioral sciences. Mahwah, NJ: Lawrence Erlbaum Associates; 1988, 2nd ed.

[42] Allen and Meyer. 'Organizational Commitment: Evidence of Career Stage Effects?'. Journal of Business Research. 1993, vol. 26, no. 1, pp. 49-61.

[43] Blau, PM., Exchange and Power in Soical Life. New York: Wiley; 1964.

[44] Dabos, GE \& Rousseau, DM. 'Mutuality and Reciprocity in the Psy chological Contracts of Employees and Employ ers'. Journal of Appied Psychology. 2004; vol. 89, no. 1, pp. $52-72$.

[45] Irving, PG, Coleman, DF \& Cooper, CL. 'Further Assessments of a Three-Component Model of Occupational Commitment: Generalizability and Differences across Occupations'. Journal of Applied Psychology. 1997; vol. 82, no. 3, pp. 444-52.
[46] March, JG \& Simon, HA., Organizations. New York, USA: John Wiley \& Sons; 1958.

[47] Morrow, PC., 'Concept Redundancy in Organizational Research - the Case of Work Commitment'. Academy of Management Review. 1983; vol. 8, no. 3, pp.486-500.

[48] Price, JL \& Mueller, CW., Absenteeism and Turnover of Hospital Employees. Greenwich, Conn: JAI Press; 1986.

[49] Mobley, W, Horner, S \& Hollingsworth, A. 'An Evaluation of Precursors of Hospital Employee Turnover'. Journal of Applied Psychology. 1978; vol. 63, no. 4, pp.408-14.

[50] Ozturk, A, Hancer, M \& Wang, YC. 'Interpersonal Trust, Organizational Culture and Turnover Intention in Hotels: A Cross Level Perspective'. Tourism Analysis. 2014; vol. 19, no. 2, pp. 139-50.

[51] Larwood, L, Wright, TA, Desrochers, S \& Dahir, V. 'Extending Latent Role and Psychological Contract Theories to Predict Intent to Turnover and Politics in Business Organizations'. Group \& Organization Management. 1998; vol. 23, no. 2, pp. 100-23.

[52] Freese, C \& Schalk, R. 'Implications of Differences in Psychological Contracts for Human Resource Management'. European Journal of Work and Organizational Psychology. 1996; vol. 5, no. 4, pp.501-9.

[53] Tekleab, A, G. \& Taylor, MS., 'Aren't There Two Parties in an Employment Relationship? Antecedents and Consequences of Organization-Employee Agreement on Contract Obligations and Violations'. Journal of Organizational Behavior. 2003; vol. 24, no. 5, pp. 585-608.

[54] Meyer, JP \& Allen, NJ., 'A Three-Component Conceptualization of Organisational Commitment'. Human Resource Management. 1991; vol. 1, no. 1, pp.61-89.

[55] Kotter, JP., 'The Psychological Contract:Managing the Joining up Process'. California Management Review. 1973; vol. 15 , no. 3 , pp. 91-9.

[56] Robinson, SL. 'Trust and Breach of the Psychological Contract'. Administrative Science Quarterly. 1996; vol. 41, no. 4, pp. 574-99.

[57] Shore, LM \& Barksdale, K. 'Examining Degree of Balance and Level of Obligation in the Employment Relationship: A Social Exchange Approach'. Journal of Organizational Behavior. 1998; vol. 19, no. 1, pp.731-44.

[58] Turnley, WH \& Feldman, DC. 'The Impact of Psychological Contract Violations on Exit, Voice, Loy alty, and Neglect'. Human Relations. 1999; vol. 52, no. 7, pp. 895-922.

[59] Lester, SW \& Kickul, J. 'Psychological Contracts in the 21st Century: What Employees Value Most and How Well Organizations Are Responding to These Expectations'. Human Resource Planning. 2001; vol. 24, no. 1, pp. 10-21.

[60] Sutton, G \& Griffin, MA. 'Integrating Expectations, Experience, and Psychological Contract Violation: A Longitudinal Study of New Professionals'. Journal of Occupational and Organizational Psychology. 2004; vol. 77, no. 4, pp. 493-514.

[61] Lemire, L \& Rouillard, C. 'An Empirical Exploration of Psychological Contract Violation and Individual 
Behaviour'. Journal of Managerial Psychology. 2005; vol. 20, no. 2, pp. 150-63.

[62] Staufenbiel, T \& Konig, CJ. 'A Model for the Effects of Job Insecurity on Performance, Turnover Intention, and Absenteeism'. Journal of Occupational and Organizational Psychology. 2010; vol. 83, no. 1, pp.101-17.

[63] Rousseau, DM. 'Psychological Contracts in the Workplace: Understanding the Ties That Motivate'. Academy of Management Executive. 2004; vol. 18, no. 1, pp. 120-7.

[64] Gilder, DD. 'Commitment, Trust and Work Behaviours'. Personnel Review. 2003; vol. 32, no. 5, pp. 588-604.

[65] Harrison, DA, Neuman, DA \& Roth, PL., 'How Important Are Job Attitudes? Meta-Analytic Comparisons of Integrative Behavioural Outcomes and Time Sequences'. Academy of Management Journal. 2006; vol. 49, no. 2, pp. 305-25.

[66] Rosen, C, Chang, C-H, Johnson, RE \& Levy, PE. 'Perceptions of the Organizational Context and Psychological Contract Breach: Assessing Competing Perspectives'. Organizational Behavior and Human Decision Processes. 2009; vol. 108, no. 2, pp. 202-17.

[67] Zhao, H, Wayne, SJ, Glibkowski, BC \& Bravo, J. 'The Impact of Psy chological Contract Breach on Work-Related Outcomes: A Meta-Analysis'. Personnel Psy chology. 2007; vol. 60 , no. 3 , pp. 647-80.

[68] Chen, CW \& Wei, YC. 'Perception of Organizational Politics Moderates the Relationship between OCB and Turnover Intention', 2009; paper presented to International Conference on Busines And Information, Kuala Lumpur, Malaysia.

[69] Khalid, SA, Jusoff, H, Ali, H, Ismail, M, Kassim, JM \& Rahman, NA. 'Gender as a Moderator of the Relationship between Ocb and Turnover Intention'. Asian Social Science. 2009; vol. 5, no. 6, pp. 108-17

[70] Castro, CB, Armario, EM \& Ruize, DM., 'Influence of Employee Organizational Citizenship Behaviors on Customer Loyalty'. International Jounral of Service Industry Management. 2004a; vol. 15, no. 1, pp.27-53.

[71] Mossholder, KW, Settoon, RP \& Henagan, SC. 'A Relational Perspective on Turnover: Examining Structural, Attitudinal, and Behavioral Predictors'. Academy of Management Journal. 2005; vol. 48, no. 4, pp.607-18.

[72] Chen, XP, Hui, C \& Sego, DJ. 'The Role of Organizational Citizenship Behavior in Turnover: Conceptualization and Preliminary Tests of Key Hypotheses'. Journal of Applied Psychology. 1998; vol. 83, no. 6, pp.922-31. 